\title{
Antiretroviral therapy, immunoreactivity and level of virus loading at the patients with co-infection HIV/ Tuberculosis
}

\begin{abstract}
Tuberculosis is one of the most often secondary diseases at the patients with HIV-infection causing a heavy defeat of various localization and being the basic reason of letal outcome at the patients with AIDS.1,2 The patients having simultaneously a tuberculosis and a HIV-infection, concern to the most difficult contingent, both among the patients with HIV-infection, and among the patients with tuberculosis.3 Presence of a HIV-infection - highest risk of tuberculosis development.
\end{abstract}

\section{Introduction}

Tuberculosis is one of the most often secondary diseases at the patients with HIV-infection causing a heavy defeat of various localization and being the basic reason of letal outcome at the patients with AIDS. ${ }^{1,2}$ The patients having simultaneously a tuberculosis and a HIV-infection, concern to the most difficult contingent, both among the patients with HIV-infection, and among the patients with tuberculosis. ${ }^{3}$ Presence of a HIV-infection - highest risk of tuberculosis development.

Mortality from tuberculosis for patients with HIV-infection is more, than at the constant population of Russia consisting on the account, in 28 times. The influence of HIV-infection on epidemic process at tuberculosis will be increased. By 2020 among the first time registered tuberculosis patients, HIV-infection can have up to $30 \%$ of the patients as a whole on Russia, and in the separate subjects of Russian Federation-till 40-50\%. The tuberculosis morbility of HIV-infected, in comparison with average parameters on Russia, among the constant population in 2012 was in 35 times more. ${ }^{4}$ The purpose of research-definition of antiretroviral therapy influence on immunoreactivety condition and level of virus loading at the patients with co-infection HIV/tuberculosis.

\section{Materials and methods}

In total 300 men were inspected. Group I-100 patients with coinfection of lung tuberculosis and HIV, not receiving antiretroviral therapy (ARVT); group II - 100 patients with co-infection of lung tuberculosis and HIV, receiving antiretroviral therapy; group III-100 patients with co-infection of drug resistant lung tuberculosis and HIV, receiving antiretroviral therapy.
Volume 4 Issue 3 - 2018

Makarov PV, Makarov VK
Tver State Medical University, Russia

Correspondence: Makarov VK, Tver State Medical University, faculty of infectious diseases and epidemiology, Russia, Email makarov.tver@mail.ru

Received: April 16, 2018| Published: June 18, 2018

\section{Results and their arguing}

The standard procedure of inspection HIV-infected patients is the definition of the immune status, in particular of CD4 lymphocytes level.

The note:

P1 - reliability of distinctions of parameters at the patients with HIV/tuberculosis 1-й and 2 groups;

P2 - reliability of distinctions of parameters at the patients with HIV/tuberculosis 1-й and 3-rd groups;

P3 - reliability of distinctions of parameters at the patients with HIV/tuberculosis 2-й and 3-rd groups.

Under of ARVT influence (Table 1) the CD4 lymphocytes level increased on 34,5\% (patients of 3-rd group) and 37,5\% (patients of 2 group) in comparison with the patients, which did not received ARVT (1-я group). For the 2 group patients the CD4 contents has made $373,8 \pm 13,6$ and $356,3 \pm 11,5$ cells / $\mathrm{mm} 3$ for the 3-rd group patients. The different is uncertain $(\mathrm{P}>0,05)$. Taking into account that the absolute metrics of the immune status can considerably vary during even of day, the definition of CD4 lymphocytes level in percentage was carried out. In this case metrics considerably differed with a high degree of reliability for the patients of 1-st group on the one hand and patients of 2 and 3-rd groups, from other (Table 2). The antiretroviral therapy resulted to rise of CD4 lymphocytes percentage almost on $40 \%$. However contents CD4 cells did not depend on the mode of antituberculosis therapy. The difference in percentage CD4 lymphocytes in group 2 and 3 has appeared statistically uncertain $(\mathrm{P}>0,05)$.

Table I Immune status parameters at the patients with HIV/tuberculosis on groups in absolute units

\begin{tabular}{|c|c|c|c|c|c|c|}
\hline \multirow[b]{2}{*}{$\begin{array}{l}\text { CD4-lymphocytes } \\
\text { parameters }\end{array}$} & \multicolumn{6}{|c|}{ Groups of the inspected persons } \\
\hline & $\begin{array}{l}\text { HIV/tuberculosis } \\
\text { group I } \\
(n=100)\end{array}$ & $\begin{array}{l}\text { HIV/tuberculosis } \\
\text { group } 2 \\
(n=100)\end{array}$ & $\begin{array}{l}\text { HIV/tuberculosis } \\
\text { group } 3 \\
(n=100)\end{array}$ & $\begin{array}{l}\mathrm{PI} \\
\mathrm{I}-2\end{array}$ & $\begin{array}{l}\mathrm{P} 2 \\
\mathrm{I}-3\end{array}$ & $\begin{array}{l}\text { P3 } \\
2-3\end{array}$ \\
\hline $\begin{array}{l}\text { CD4- lymphocytes } \\
\text { parameters cells } / \mathrm{mm}^{3}\end{array}$ & $233,3 \pm 13,9$ & $373,8 \pm 13,6$ & $356,3 \pm 1 I, 5$ & $<0,001$ & $<0,00$ । & $>0,05$ \\
\hline
\end{tabular}


Table 2 Immune status parameters at the patients with HIV/tuberculosis on groups in \%

\begin{tabular}{|c|c|c|c|c|c|c|}
\hline \multirow[b]{2}{*}{$\begin{array}{l}\text { CD4-lymphocytes } \\
\text { parameters }\end{array}$} & \multicolumn{6}{|c|}{ Groups of the inspected persons } \\
\hline & $\begin{array}{l}\text { HIV/tuberculosis } \\
\text { group I } \\
(n=100)\end{array}$ & $\begin{array}{l}\text { HIV/tuberculosis } \\
\text { group } 2 \\
(\mathrm{n}=100)\end{array}$ & $\begin{array}{l}\text { HIV/tuberculosis } \\
\text { group } 3 \\
(n=100)\end{array}$ & $\begin{array}{l}\mathrm{PI} \\
\mathrm{I}-2\end{array}$ & $\begin{array}{l}\mathrm{P} 2 \\
\mathrm{I}-3\end{array}$ & $\begin{array}{l}\text { P3 } \\
2-3\end{array}$ \\
\hline $\begin{array}{l}\text { CD4- lymphocytes } \\
\text { parameters in \% }\end{array}$ & $|3,| \pm \mid, 5$ & $21,3 \pm 1,3$ & $20,3 \pm 1,20$ & $<0,00 \mid$ & $<0,001$ & $>0,05$ \\
\hline
\end{tabular}

\section{The note}

P1-reliability of distinctions of parameters at the patients with HIV/tuberculosis 1-й and 2 groups;

P2-reliability of distinctions of parameters at the patients with HIV/tuberculosis 1-й and 3-rd groups;

P3-reliability of distinctions of parameters at the patients with
HIV/tuberculosis 2-й and 3-rd groups.

One of main laboratory markers of HIV progressing now is the definition of HIV virus load (concentration of HIV RNA in blood). We pars metrics for the patients with a co- infection a HIV/tuberculosis in dependence of the antituberculosis therapy mode from spent or not spent ARVT (Table 3).

Table 3 Parameters of virus loading at the patients with co-infection HIV/tuberculosis on groups in absolute units

\begin{tabular}{|c|c|c|c|c|c|c|}
\hline \multirow[b]{2}{*}{$\begin{array}{l}\text { Parameters of virus } \\
\text { loading }\end{array}$} & \multicolumn{6}{|c|}{ Groups of the inspected persons } \\
\hline & $\begin{array}{l}\text { HIV/tuberculosis } \\
\text { group I } \\
(\mathrm{n}=100)\end{array}$ & $\begin{array}{l}\text { HIV/tuberculosis } \\
\text { group } 2 \\
(\mathrm{n}=100)\end{array}$ & $\begin{array}{l}\text { HIV/tuberculosis } \\
\text { group } 3 \\
(\mathrm{n}=100)\end{array}$ & $\begin{array}{l}\text { PI } \\
\text { I-2 }\end{array}$ & $\begin{array}{l}\text { P2 } \\
\text { I-3 }\end{array}$ & $\begin{array}{l}P 3 \\
2-3\end{array}$ \\
\hline Virus loading, сору/мл & $12000000 \pm 72000$ & $68000 \pm 1200$ & $71000 \pm 1100$ & $<0,001$ & $<0,001$ & $>0,05$ \\
\hline
\end{tabular}

\section{The note}

P1-reliability of distinctions of parameters at the patients with HIV/tuberculosis 1-й and 2 groups;

P2-reliability of distinctions of parameters at the patients with HIV/tuberculosis 1-й and 3-rd groups;

P3-reliability of distinctions of parameters at the patients with HIV/tuberculosis 2-й and 3-rd groups.

The essential decrease of virus loading under influence of antiretroviral therapy at the patients with lung tuberculosis, as receiving treatment on 1-st standard mode, and at the patients with drug resistant was established. Virus loading between the patients with 2 and 3 groups differed unsignificantly $(\mathrm{P}>0,05)$.

\section{Conclusion}

Antiretroviral therapy resulted to increase absolute and percentage CD4-lymphosites, that is to activation of immune responses, which outcome was the difference in a level of HIV virus load for patients receiving ARVT comparison with not receiving ones practically in 176 time.

\section{Acknowledgments}

None.

\section{Conflict of interest}

The author declares that there is no conflict of interest.

\section{References}

1. Dolgova EA, Alvares Figeroa MV, Lobasheva GP. Definition of medicinal stability to rifampicine at the patients with tuberculosis which is taking place at a stage of secondary diseases of HIV-infection. Tub $i$ bolezni legkih. 2014;4:129-130.

2. Panteleev AM. Tuberculosis with medicinal stability MBT at patients with HIV-infection. Aktual probl i perspektivy protivotuberkuleznoj sluzhby v RF: Materialy I Kongressa Nacionalnoj associacii ftiziatrov; 2012: 281-283.

3. Frolova OG, Shchukina IV, Frolov GG. The mortality analysis from tuberculosis, connected with HIV-infection. Tuberkulyoz i bolezni legkih. 2014;7:32-36.

4. Nechaeva OB. A situation on a tuberculosis and HIV-infection in Russia. Tuberkulyoz i bolezni lyogkih. 2014;6:9-15. 